\title{
Administrative Functions of Implementation AND Adjudication Guided by Primacy of Fundamental Rights
}

\author{
Ricardo Perlingeiro* \\ Fluminense Federal University and \\ Estácio de Sá University, Brazil
}

\begin{abstract}
This article points out the bottlenecks in the systems of administrative adjudication in Latin America and suggests that the ineffectiveness should not be blamed entirely on the judicial system and judicial procedures. Rather, the Latin-American system of administrative justice should come to terms with its judicial system of general jurisdiction, gradually reducing the jurisdiction of courts over administrative disputes in favor of an administrative reform to ensure administrative functions of implementation and adjudication respecting the primacy of fundamental rights. The author concludes that it is necessary to think about a reform that leads public administrative authorities to act as an instrument for expressing the public interest rather than as end in itself or as an entity to protect self-serving, momentary political and financial interests that are not clearly bound by a duty to protect fundamental rights.
\end{abstract}

\section{CONTENTS}

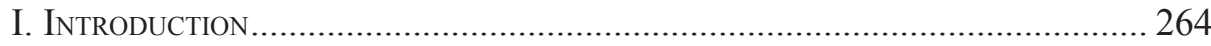

II. Current Trends in Administrative Adjudication .................................. 264

A. Judges Who Are Administrative Law Specialists and Independent... 264

B The Three Dimensions of the Fair Trial in the Administrative Justice ......265

C. Two Very Different Approaches to Judicial Organization ................. 266

D. Serious Problems in Latin-American Systems of Administrative

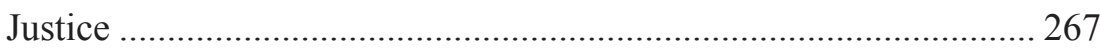

E. What Is the Solution? ................................................................. 268

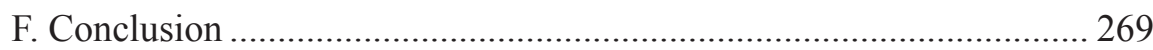

III Annex: Terminology and Specific Procedural Issues .......................... 270

A. Specialized Courts in Latin America............................................. 270

B Administrative Agencies ..................................................... 271

* Full Professor of the Faculty of Law of Fluminense Federal University (Niterói, Rio de Janeiro). Professor of Estácio de Sá University / MA and PhD Programs in Law (Rio de Janeiro). Federal Appellate Judge (Desembargador Federal) of the Federal Regional Court of the $2^{\text {nd }}$ Region (Rio de Janeiro). 
C. Principle of Party Autonomy........................................................ 271

D. Control of Exercise of Discretionary Powers ........................... 272

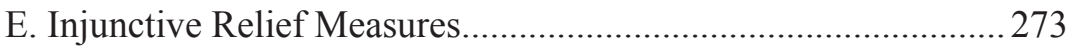

F. Enforcement of Judgments Against Authorities ........................ 273

G. Excessive Litigation in Brazil...................................................2 274

H. Conventionality Control or Review of Compliance with

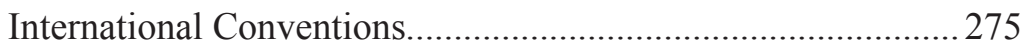

I. Model Code of Administrative Procedure in Judicial and

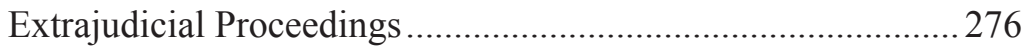

J. Euro-American Model Code of Administrative Justice .............. 277

\section{INTRODUCTION}

This article is derived from a lecture entitled "The Reform of Administrative Justice In Latin America" (Реформа административной юстиции в Латинской Америке) given in the international conference Administrative justice: comparative and Russian contexts held in Tyumen on September 29-30, 2016 in the framework of the 2nd Siberian Legal Forum devoted to the development of administrative legal proceedings in Russia. It is divided into two parts; the first part covers the original contents of the talk (trends in administrative adjudication), with references in the footnotes. The second part concerns the main issues (specific features and terms adopted) that were discussed at the event, explaining certain concepts and institutions of Latin-American administrative law, particularly in Brazil. ${ }^{1}$

\section{Current Trends in Administrative Adjudication}

\section{A. JUdGES Who ARE ADMINISTRATIVE LAW SPECIALISTS AND INDEPENDENT}

According to Articles 8.1 and 25 of the American Convention on Human Rights, the right to effective judicial protection, a primary focus of the Rule of Law in Latin America, means the right to a competent, independent and impartial tribunal or court, guaranteeing due process of law, for the determination of individual rights, including those of an administrative nature. In the field of the administrative justice, the prerequisites for such protection are judges who are administrative law specialists and independent from the authorities responsible for the challenged

\footnotetext{
This text was inspired by the article Contemporary Challenges in Latin American
} Administrative Justice, 3 BRICS L.J. 2, 21-56 (2016). 
decisions, as well as the reinforcement of procedural principles that enable weighing private interests against public interests. ${ }^{2}$ Pioneering efforts to establish such a self-standing, independent branch of administrative justice include the German administrative tribunal of Baden of $1864^{3}$ and the French Law of Reorganization of the Conseil d'Etat of $1872 .{ }^{4}$ Although no such division has been adopted in Latin American countries, the independence of the courts is considered to be an indispensable element of the contemporary justice system, as is expressly stated in the national and international laws and conventions in force. ${ }^{5}$

\section{B. The Three Dimensions of the Fair Trial in the Administrative Justice}

In keeping with the Inter-American system of human rights, the statutes and case law of many Latin-American countries have identified three dimensions of the right to effective judicial protection in administrative disputes. ${ }^{6}$

First, the judicial protection must be complete. ${ }^{7}$ The review of procedural and substantive lawfulness must include, where appropriate, a verification of whether the administrative authority exceeded the limits of its discretionary powers. ${ }^{8}$ In principle, government acts are subject to judicial review, ${ }^{9}$ but the question is still controversial in certain countries. ${ }^{10}$

2 Ricardo Perlingeiro, Brazil's Administrative Justice System in a Comparative Context, 1 Revista de Investigações Constitucionais, 3, 37 (2014), available at SSRN: https://ssrn.com/abstract=2310109.

3 Eckart Hien, The Role of the Administrative Jurisdiction in Society and in the Development of the European Union, 16 (2005), available at: http://bit.ly/2eSnHWi .

4 Loi du 24 mai 1872 sur la réorganisation du Conseil d'État [Law of 24 May 1872 on the Reorganisation of the State Council].

5 Ricardo Perlingeiro, A Historical Perspective on Administrative Jurisdiction in Latin America: Continental European Tradition Versus U. S. Influence, Br. J. Am. Leg. Studies 5, 269 (2016).

6 The three dimensions of the right to a fair trial in administrative justice were formulated by Karl-Peter Sommermann and Ricardo Perlingeiro upon conclusion of the Euro-American Model Code of Administrative Jurisdiction research project (Ricardo Perlingeiro \& Karl-Peter Sommermann, Euro-American Model Code of Administrative Jurisdiction, 2-3 (2014)).

7 Case of Barbani Duarte et al. v. Uruguay, Inter-Aм. Cт H. R., ๆ 204 (Oct. 13, 2011), available at: http://bit.ly/29rEwZX.

8 Exp: 04-011636-0007-CO, Res. 03669-2006, Constitutional Section of the Supreme Court of Justice of Costa Rica [Sala Constitucional de La Corte Suprema de Justicia DE Costa RICA], (Mar. 15, 2006), available at: http://bit.ly/2go4q0o. See Ernesto Jinesta, Principio general de la justiciabilidad plenaria y universal de la conducta administrativa, 607-34 (2014), available at: http://bit.ly/2ggBA67. Incidentally, according to art. 15 of the General Public Administration Act of Costa Rica [Ley General de la Administración Pública] / Law n ${ }^{\circ}$ 6.227, of 28 April 1978, the judge "shall act as comptroller to ensure the legality of the various aspects of the discretionary administrative decision and observance of the limits thereof." On the subject of substantive review of administrative decisions, see art. 51 of the Mexican Federal Law of Administrative Justice [Ley Federal de Procedimiento Contencioso Administrativo], of 4 October 2005.

9 See generally Jinesta, supra note 9, and Juan Carlos Cassagne, La Judicialización de LAS CUESTIONES POLÍTICAS, available at: http://bit.ly/2fxyNUY.

10 Art. 6 (c) of the Ecuadorian Law of Administrative Justice recognizes the category political acts of government and exempts them from judicial review; Art. 3 (II) (a) of 
Second, the judicial protection must cover every type of conduct of public authorities. Judicial review must cover not only an administrative authority's acts or decisions that restrict the a citizen's rights but also any negligence or culpable omissions on the part of that authority. In other words, procedural law must ensure that citizens are able to resort to the courts not only to challenge administrative decisions or acts that affect them adversely but also the authority's failure to reply to a request or to provide a benefit to which the claimant believes himself to be entitled. The court must have both the authority to rule on the administrative authority's obligations and the necessary powers of enforcement to guarantee that their ruling will actually be put into practice. ${ }^{11}$

The third dimension of effective judicial protection concerns the timeliness of the protection. Judicial protection that comes too late is hardly helpful. Procedural law should therefore enable interim relief to be obtained quickly and easily in urgent cases, through petitions to prevent acts of undue interference by the administrative authority or to obtain declaratory judgments in case of danger in delay. The court should be able to order the administrative authority to perform or to refrain from performing an act. Interim relief should be available whenever interference with the citizen's rights could have irreparable consequences. ${ }^{12}$

\section{Two VerY DiffERENT ApProaCHES to JUDICIAL ORGANIZATION}

Two very different approaches to judicial organization have been taken to create a specialization in administrative adjudication. In general, in common-law countries (especially in the United States, United Kingdom and Australia) there are no specialized administrative courts but rather highly specialized quasi-judicial bodies within the

the Bolivian Law of Administrative Procedure stipulates that "governmental acts based on the power to freely appoint and remove authorities" are not subject to the provisions of that same Law of Administrative Procedure; according to art. 4 (b) of the Law of Administrative Justice of Honduras, administrative courts have no authority to examine issues raised by "actions involving the relationship between Branches of Government or occasioned by international relations, defense of the national territory or military command and organization"; Art. 4 (a) of the Law of Administrative Justice of El Salvador; Art. 21.1 and art. 21.2 of the Law of Administrative Justice of Guatemala; and art. 17.1 of the Law of Administrative Justice of Nicaragua.

11 Case of Barbani Duarte et al. v. Uruguay, InтER-Aм. Cт H.R., 201 (Oct. 13, 2011), available at: http://bit.ly/29rEwZX. Along the same lines: Arts. 4 and 5 of the Peruvian Law of Administrative Justice [Ley que regula el Proceso Contencioso Administrativo] / Law $\mathrm{n}^{\circ}$ 27.584, of 22 November 2001; Art. 9 of the Organic Law of Administrative Justice of Venezuela [Ley Orgánica de la Jurisdicción Contencioso Administrativa] / Law n ${ }^{\circ}$ 39.447, of 16 June 2010; Art.14 of the Law of Administrative Justice of Nicaragua [Ley de Regulación de la Jurisdicción de lo Contencioso Administrativo] / Law n ${ }^{\circ} 350$, of 18 May 2000.

12 Art. 230 of the Colombian Law of Administrative Procedure and Administrative Justice [Código de Procedimiento Administrativo y de lo Contencioso Administrativo] / Law n ${ }^{\circ}$ 1437, of 18 January 2011; Art. 24 of the Mexican Federal Law of Administrative Justice; Art. 18 of the Law of Administrative Justice of Guatemala [Ley de lo Contencioso Administrativo] / Decree n 119, of 17 December 1996; Arts. 69 and 103-106 of the Organic Law of Administrative Justice of Venezuela. 
administrative agency themselves. Given the high degree of expertise of those bodies in the relevant areas of administrative law, the courts generally show deference to their decisions with respect to questions of fact, ${ }^{13}$ and merely perform a "closed review" limited to questions of legality and procedure. ${ }^{14}$ Such judicial deference is made up for by the availability of "intra-administrative" dispute-resolution mechanisms within the agency (administrative tribunals, adjudicators, adjudicative bodies) which are endowed with quasi-judicial powers and sufficient independence to provide citizens with guarantees of due process of law and a fair hearing.

In most Continental European legal systems with civil law origins in contrast, the courts have a special division for cases, which tends to have broad powers to review the factual grounds for administrative decisions (an open judicial review). Such broad powers of review are intended to counterbalance the traditional absence of internal dispute-resolution mechanisms within the administrative authorities themselves. ${ }^{15}$ Thus, regardless of the organizational system, administrative justice is always placed in hands of specialized adjudicators. The difference is that in the "Continental European" approach, administrative disputes are resolved by specialized judges within the Judiciary, whereas in the United States quasi-judicial bodies within the administrative agency play a decisive role, although they remain subject to relatively deferential closed review by the Judiciary.

\section{Serious Problems in Latin-American Systems of Administrative Justice}

This dichotomy has given rise to serious problems in Latin-American systems of administrative justice.As former Iberian colonies, the countries of Latin America inherited the Continental European legal culture, with its civil law tradition. Since the early $19^{\text {th }}$ Century, however, U.S. Constitutional law has exercised a strong influence on Latin-American countries. As a result, most of them have adopted a judicial system with "general jurisdiction," meaning that the same courts handle both ordinary and administrative disputes. ${ }^{16}$ Since those countries have not managed to cut all their ties with the European legal culture, however, their adoption of the U.S. model of general jurisdiction has not been entirely successful. Countries that have organized their Judiciary with general jurisdiction are now suffering from the weaknesses of both predecessor systems: the lack of specialized administrative courts in the U.S. model, combined with the absence of quasi-judicial bodies within the administrative authorities themselves, which is typical of the Continental European model. ${ }^{17}$

13 See Peter Cane, Administrative Law, 96 (5th ed. 2011). See also Peter L. Strauss, An Introduction to Administrative Justice In the United States (1989).

14 See generally Michael Asimow, Five Models of Administrative Adjudication, 63 Ам. J. Comp. L. 3, 8-9 (2015).

15 On the subject of European models of administrative justice, see Michel Fromont, Droit Administratifs des Ėtats Européens [Administrative Law of the European States] 120 et seq. (2006). See also Jacques Ziller, Administrations Comparées: Les systémes Politico-Administratifs de L'Europe des Douze [Compared Administrations: the Politico-administrative Systems of the Europe of the Twelve] 381 (1993).

16 See Perlingeiro, supra note 6.

17 Id. at $245-46$. 
The adoption of a judicial system with courts of unified jurisdiction within a predominantly Continental European legal culture has led to the following situation in Latin America. At one extreme, in courts of general jurisdiction, Latin American judges are tempted to imitate the U.S. courts by refusing to review questions of fact underlying the challenged administrative decisions, merely checking for possible violations of the principles of legality and (above all) procedural due process. ${ }^{18}$ Such deference to administrative authorities gives Latin Americans the impression of the immunity of the State that makes them feel vulnerable, since decisions are made by administrative authorities that lack the necessary prerogatives to exercise their duties independently, without having to fear negative repercussions from other authorities.

At the other extreme, the broad powers of review of administrative decisions enjoyed by Latin American courts, based on the European model, may paradoxically lead to undermining the effectiveness of judicial protection. Given the absence of specialized administrative courts, judges with excessively broad powers are able to rule on cases involving administrative agencies as though they were disputes between individuals, without due consideration for public interests; in other words, they tend to apply principles of private law and civil procedure to disputes with public administrative authorities. ${ }^{19}$ This is especially true in Brazil, which, to this very day, still has no general code of judicial procedure for administrative adjudication. ${ }^{20}$

As we have seen, the justice system in Latin America has serious deficiencies.

\section{E. What IS the Solution?}

After over two centuries of a judicial system consisting solely of courts of general jurisdiction, it would not seem the best option at this point to start discussing specialization of the courts. Indeed, the future of Latin American administrative justice depends on compensating for the lack of specialized administrative courts by endowing administrative agencies with guarantees of procedural due process, as established by the $5^{\text {th }}$ and 14th Amendments to the U.S. Constitution and adopted by most Latin American national constitutions. ${ }^{21}$

Yet there is another problem, as well. It is indispensable for the state to provide independent and impartial dispute-resolution mechanisms, whether exercised by the courts in fair trials, or by the public authorities in fair hearings. Similarly, the

18 Chevron U.S.A., Inc, v. Natural Resources Defense Council, Inc. 467 U.S. 837 (1984).

19 Dicey considered "the possibility of suing government officials in the ordinary courts according to principles of private law to be a element of the rule of law", which is now facilitated in common-law systems by a fair hearing in the administrative phase (CANE, supra note 14, at 44), and does not yet exist in practice in Latin America.

20 Ricardo Perlingeiro, Due Process Prior to Administrative Decision and Effective Judicial Protection in Brazil: A New Perspective? Vienna J. InT'L Const. L., 10, 30-62 (2016).

21 Const. of Colombia (1991) art. 29; Const. of Brazil (1988) art. 5 LiV and LV; Const. of Venezuela (1999) art. 49; Const. of Dominican Republic (2010) art. 69; Const. of Nicaragua (1995) art. 34; in Ecuador, art. 23.27 of the Constitution of 1998 and arts. 76 and 169 of the Constitution of 2008. 
executive duties (implementation functions) falling within the competence of the administrative authorities must not be left out of the equation, because it is the faulty performance of such duties that is the root cause of individual complaints against the administrative agencies.

The increasing number of such disputes is an obvious sign that the administrative agencies are not functioning properly and that citizens have lost faith in their primary activities (implementation functions), or at least have greater faith in the courts than in the administrative authorities. Civil servants commonly tell citizens that although their claims may be well-founded they have no chance of success within their own agency, so that they should assert their claim in court. The primary question is what the role of the executive agencies should be in contemporary society. Should they merely apply administrative regulations and statutes to the letter, or should they also respect the guarantees of fundamental rights under national constitutions, international conventions and case law of international courts of human rights?

Although it may seem obvious that administrative authorities should seek to protect fundamental rights, the question is how they should do so. What structure should be used? Do civil servants in decision-making positions require legal qualifications? Do they need to be independent? ${ }^{22}$ Do they need to be impartial? It is time for us to look for a model of administrative authorities that are equipped with (quasi-judicial) instruments allowing them to be guided by the public interest and by the principle of proportionality in order to make difficult choices when confronted with conflicting fundamental rights in favor of an individual or a community.

It is a rather thorny issue but needs to be addressed, especially now that the notion of "diffuse conventionality control" has been introduced by the InterAmerican Court of Human Rights. According to that concept, formulated in 2014 in the Case of Expelled Dominicans and Haitians v. the Dominican Republic, the duty to comply with American Convention of Human Rights, as interpreted by the Inter-American Court, extends to all administrative agencies, without exception. ${ }^{23}$

It is therefore necessary to rethink the current model of public administrative authorities in Latin America; should they continue to be entities inseparable from the government, with key decision-making positions occupied by officials who are appointed and removed on the basis of political criteria rather than qualifications and expertise? In fact, the extent to which the Judiciary requires a branch specializing in administrative disputes is inversely proportional to the degree to which administrative authorities play their role properly: the more effective the protection of fundamental rights by administrative agencies, the more citizens will have faith in them and the more deference will be shown to them by the courts, and thus the less need there will be for specialized administrative courts.

\section{F. CONCLUSION}

In conclusion, it is time to stop pinning all the blame for the ineffectiveness of administrative justice on the judicial system and laws of procedure alone. On the

\footnotetext{
22 Case of Palamara Iribarne v. Chile, InTER-Aм. CT. H.R., 9 (c) (Nov. 22, 2005), available at: http://bit.ly/2408ANi. Concurring opinion of Judge Sergio García Ramírez.

23 Case of Expelled Dominicans and Haitians v. Dominican Republic, Inter-Am. Cт H. R., ๆ 497 (Aug. 28, 2014).
} 
contrary, Latin America should come to terms with its judicial system of courts of general jurisdiction, while progressively reducing the role played by the courts in administrative disputes thanks to an administrative reform ensuring the primacy of fundamental rights in the implementation and adjudication functions of the agencies.

We need to think about a reform that would induce administrative authorities to act as a voice of the public interest rather than as an end in themselves or as entities for the protection of their own momentary financial and political interests that are not clearly bound by a duty to protect fundamental rights.

\section{Annex: Terminology and Specific Procedural Issues}

\section{A. Specialized Courts in Latin America}

When I refer to "specialised courts", I mean "a branch" of the Judiciary devoted to conflict resolution in the area of administrative law, in which the judges are hired for the expertise in administrative law and always work in that field of specialisation.I do not consider "specialised courts" to include courts whose judges are not appointed by law to act exclusively and specifically in a court specializing in administrative law. Latin America generally has courts of general jurisdiction (including both private law and administrative law). ${ }^{24}$ They are specialized only under certain circumstances, at certain times or in certain places, through the internal organization of the Judiciary itself, without uniformity and with no guaranteed tenure of the judges who perform such specialized duties. In Brazil, for example, there is the Federal Justice System, which approximates the concept of a specialized court but is not exactly a court specializing in administrative law. Since Brazil is a 3-level federal republic, the Federal Justice System exercises jurisdiction over administrative law in cases of interest to the federal administrative authorities.

Yet this involves not only conflicts of administrative law, but also conflicts between private citizens as well as criminal cases of interest to the federal administrative authorities. The federal judges are not hired solely for their expertise in administrative law and are not guaranteed a permanent position in bodies specializing exclusively in administrative law. Over the course of their career, they may be transferred to other bodies of the Federal Justice System.

Thus, in my opinion, there are no special administrative law courts in Brazil, or in

24 Const. of Bolivia (2008) art. 179; Const. of Brazil (1988); Const. of Costa Rica (1949); Const. of El SAlVAdor (1983) art. 131.31; Const. of ECUAdor (2008) arts. 188.3 and 173; Const. of Honduras (1982); Art. 163 of the Law partially amending the Constitution of the Republic of Nicaragua (1987). See Corte Suprema de Justicia de República de Nicaragua, Sala de lo Contencioso Administrativo. Antecedentes y Creación de la Sala de lo Contencioso Administrativo [Administrative Law Division of the Courts: History and Creation of Administrative Litigation], 2016; Const. of Panama (1972) art. 206; Const. of Paraguay (1992) art. 248. On the "judicialist" Paraguayan system in which the Judiciary exercises jurisdiction over administrative disputes, see Luis Enrique Chase Plate, La Justicia Constitucional y la Justicia Administrative in Derecho administrativo iberoamericano, 2, 1212 (Víctor Hernández-Mendible, ed., 2007). 
Latin America in general, with the exceptions of Colombia, Guatemala, Dominican Republic, Uruguay and Mexico, which have real specialized administrative law courts. $^{25}$

\section{B ADMINISTRATIVE AgENCIES}

When I refer to administrative agencies, I am thinking of the U.S. model of adjudication of administrative disputes. Administrative agencies are bodies of the Public Administration, which I consider synonymous with the term "administrative authorities". Such authorities or agencies may do double duty, with purely executive duties typical of bodies of the Executive Branch, as well as quasi-judicial duties of adjudication to resolve disputes between citizens and public administrative authorities.

The agencies and authorities that exercise quasi-judicial duties of adjudication are also called administrative tribunals, which are not to be confused with administrative courts. Administrative tribunals are bodies of the Executive Branch (agencies and authorities), typical of the adjudicative models of the United States, United Kingdom and Australia; ${ }^{26}$ administrative courts are specialized bodies of the Judicial Branch, typical of the adjudicative models of Continental Europe. Brazil and Latin America have adopted the U.S. model's courts of unified jurisdiction but without incorporating the compensatory mechanism typical of the U.S. system, namely intra-administrative dispute resolution through specialized administrative tribunals or quasi-judicial bodies within the agencies or administrative authorities themselves. In Latin America, there are no extra-judicial bodies capable of final and enforceable decisions in conflicts between citizens and public administrative authorities. Only the courts of the Judiciary are empowered to issue a final and enforceable judgement in such cases. The only exceptions are Uruguay and Mexico, which have court-like tribunals outside the Judiciary. ${ }^{27}$

\section{PRINCIPLE OF PARTY AUTONOMY}

I wish to say a few things about the principle of party autonomy, a term borrowed from Dr. Nataliya Bocharova, who discussed the subject so well in Volume 3 of the Brics Law Journal. ${ }^{28}$

25 Const. of Colombia (1991) art. 231; Const. of Guatemala (1945) art. 164, (1956) arts. 193 and 194, (1965) art. 255 and (1985) art. 221; Const. OF the Dominican RePublic (2010) arts. 164 and 165; Const. of Uruguay (1967) arts. 307 to 321; Const. of MeXico (1917) art. 73 XXIX, 94, $116 \mathrm{~V}$ and 122 Base Quinta. On the nature of Federal Administrative Tax Court, see Emilio Margáin Manautou, De lo Contencioso Administrativo: De Anulación o de Ilegimidade, 2 et seq. (2009); Const. of Mexico (1917) art. 107 IV and $\mathrm{V}$ (b). On the subject of judicial review of the public administrative authorities in general, see Jorge Fernández Ruiz, Panorama General del Derecho Administrativo Mexicano [General Overview of Mexican Administrative Law] in S. GonZÁlez-VARAS IBÁÑEZ, EL DERECHO ADMINISTRATIVO IBEROAMERICANO, 462-463 (2005). On the nature of the "autonomous tribunal" relative to the Judiciary of the administrative tribunals of Mexico and Uruguay, see PerlingeIro, supra note 6.

26 See in general Peter Cane, Administrative Tribunals and Adjudication (2009).

27 Perlingeiro, supra note 6.

28 N. Bocharova, Party Autonomy in Administrative (Judicial) Proceedings, 3 BRICS L. J., 
The principle of party autonomy, also known as the dispositive principle, gives rise to arbitration and other mechanisms of consensual dispute resolution between citizens and public administrative authorities. In Brazil, the term "direitos indisponiveis" ("inalienable" or "unavailable" rights), which sets the limits of the principle of party autonomy, is not well defined. Such "inalienable rights" are often confused with the interests of the administrative authorities. ${ }^{29}$ In fact, however, only "public interests" rather than the interests of the administrative authorities should qualify as "inalienable rights". This means that in Brazil, in practice, only questions of private law involving administrative authorities are subject to the principle of party autonomy and related consensual dispute resolution mechanisms, such as arbitration and mediation. ${ }^{30}$ I'm sorry to say that this lack of distinction between the public interest and the interests of the public authorities is the fault of the justice system and procedural laws in matters of administrative law. Since it is not necessary to determine whether a dispute should be classified as a matter of administrative law or ordinary law in order to assign it to an ordinary court or specialized administrative law court, there is no reason to define detailed criteria to distinguish between the public interest and the interests of the authorities.

Brazil's backwardness in arbitration and other means of consensual conflict resolution between authorities and citizens can also be explained by the low level of expertise of the civil servants in charge of decision-making within the administrative agencies. In addition to better legal training, Brazilian civil servants should be provided with institutional guarantees allowing them to make independent and impartial decisions without fearing negative repercussions from other authorities.

\section{Control of Exercise of Discretionary Powers}

In a judicial review to determine whether or not an administrative authority exceeded its proper margin of discretion, several factors must be taken into account; the greater the authority's independence, impartiality, legal qualifications and specialized expertise in specific subject areas, such as health, environment and energy, the less likely it is to make arbitrary decisions and the less judicial review will be necessary. ${ }^{31}$ In practice, administrative authorities endowed with such characteristics should be granted a greater margin of discretion and the resulting decisions should be shown greater deference by ordinary courts of law. Since the authorities generally lack such characteristics in Brazil, the courts have full powers to review the exercise of their discretionary powers. ${ }^{32}$ In that situation,

2, 153-163 (2016).

29 Arts. 345, II, 292 and 373, ๆ 3, I of the Brazilian Civil Procedure Code [Código de Processo Civil Brasileiro] / Law n. 13.105, of 16 March 2015.

30 Art. 1, 1 of the Arbitration law [Lei de arbitragem] / Law n ${ }^{\circ}$ 9.307, of 23 September 1996, whose wording was adopted by Law ${ }^{\circ} 13.129 / 2015$; Art. $3^{\circ}$ of Law on mediation between individuals as a mechanism of consensual and amicable dispute resolution in conflicts involving public adminstrative authorities [Lei sobre mediação entre particulares como meio de solução de controvérsias e sobre a autocomposição de conflitos no âmbito da administração pública] / Law no 13.140, of 26 June 2015.

31 See Ricardo Perlingeiro, Contemporary Challenges in Latin American Administrative Justice. 3 BRICS L. J., 2, 52 (2016).

32 See Perlingeiro, Due Process, supra note 21, at 35-36 (2016). 
judicial review of administrative powers always reveals that the authorities exceed their statutory limits of authority or violate fundamental rights and principles such as equality before the law, proportionality and legitimate expectations. Such assertions are not provided for by law but that is what happens in practice in Brazil. ${ }^{33}$

\section{E. INJUNCTIVE RELIEF MEASURES}

Regarding injunctive relief measures, first of all it should be remembered that Brazil does not have a specific code of procedure for administrative law cases. We use the Code of Civil Procedure, which contains certain specific articles for causes of interest to the administrative authorities, but in general administrative law cases are governed by the same rules of procedure as private-law cases. ${ }^{34} \mathrm{In}$ this context, in principle, non-specific injunctive measures (including measures to preserve the status quo pending final judgment or to join similar claims in the interests of procedural efficiency) are permitted for any type of claim against the administrative authorities. A common example of an unspecified injunctive relief measure is a provisional court order instructing the authorities to supply a medicine or health care service to a private claimant. If the authority fails to comply with the court order, the judge is empowered to seize the corresponding amount of money and pay it to the claimant.

There are certain restrictions on granting injunctive relief, however: general and specific restrictions. One example of a general restriction is protection of the public interest ${ }^{35}$ no such measure can be granted if it would create a risk of harming the public interest. An example of a specific restriction is the prohibition on injunctive relief to increase the remuneration of civil servants. ${ }^{36}$

\section{F. ENFORCEMENT OF JUDGMENTS AGAINST AUTHORITIES}

The traditional form of enforcement of orders instructing an administrative authority to pay a certain amount is called "precatório". ${ }^{37}$ It consists of an extrajudicial administrative procedure in which the administrative authority asks the Legislative Branch for budgetary resources and, once such funds are available, they are passed on to the Judiciary, which then pays the claimant. ${ }^{38} \mathrm{In}$ case of urgent need, however, case law allows for debt enforcement against the authorities, that is to say enforcement through expropriation of public funds that

33 AI 800.892, Agr/BA, Federal Supreme Court of Brazil [Supremo Tribunal Federal] (Mar. 12, 2013); RMS 24.699, Federal Supreme Court of Brazil [Supremo Tribunal FEDERAL] (Jun. 01, 2005).

34 Perlingeiro, Due Process,supra note 21, at 10, 43 (2016).

35 Art. 15 of the Law of Individual and Collective Writs of Mandamus [Lei do Mandado de segurança individual e coletivo] / Law $\mathrm{n}^{\circ}$ 12.016, of 7 August 2009.

36 Art. 2-B of the Law $n^{\circ}$ 9.494, of 10 September 1997, that establish the applicability of interim relief measures against the administrative authorities.

37 Const. of Brazil (1988) art. 100.

38 Ricardo Perlingeiro, Excecução contra a Fazenda Pública, 115-118 (1999). 
are not allocated to an essential public service. ${ }^{39}$ The enforcement of other types of claims against the authorities (not involving orders to pay) is handled in the same way as enforcement of judgments against private entities. That is to say, they are enforcement measures of financial coercion, such as an order to a civil servant to pay a per-diem fine payable by the civil servant until he complies with a court order. ${ }^{40}$

In practice, however, such enforcement must respect public interests (although there are no provisions of the Code of Civil Procedure specifying the public interest as a factor limiting the enforceability of judgments against the authorities). The only restrictions on the enforcement of judgments against public administrative authorities are provided by certain specific procedural laws. ${ }^{41}$

\section{G. EXCESSIVE LITIGATION IN BRAZIL}

There are at least 65 million administrative law cases pending trial in Brazil, about 40 million of which concern the enforcement of decisions by the tax office that restrict individual rights. ${ }^{42}$ Most of the claims are repetitive, mainly because even when the court rules in favor of an individual's claim based on a general interest to society, the administrative authorities do not willingly recognize the same right among the general public. For example, if a court grants one civil servant's claims for a salary adjustment, the other civil servants must each go to court in order to obtain the same benefit. The authorities prefer to await a final decision of the Supreme Court, which means there is a tendency for all the civil servants to file a new legal action.

Another major cause for the high number of legal actions in Brazil is that authorities tend to use the Judiciary as a means of enforcing their administrative decisions that restrict individual rights. ${ }^{43}$ In general, the authorities do not have

39 Agravo de Instrumento/RJ 0000305-30.2016.4.02.0000, Federal Regional Court of the $2^{\mathrm{ND}}$ Region [Tribunal Regional Federal da $2^{\mathrm{a}}$ Região] (Feb. 23, 2016), available at : http://bit.ly/2gea9Y5.

40 Apelação Civil/RJ 0000268-65.2012.4.02.504, Federal Regional Court of the $2^{\text {ND }}$ Region [Tribunal Regional Federal da $2^{\text {a }}$ Região] (Apr. 19, 2016), available at: http://bit.ly/2f2v3eU.

41 Art. $12 ~ \llbracket 1^{\circ}$ Law on Public Class Actions [Lei de Ação Civil Pública] / Law n ${ }^{\circ} 7.347$, of 24 July 1985; Art. 15 of the Law of Individual and Collective Writs of Mandamus [Lei do Mandado de segurança individual e coletivo] / Law n ${ }^{\circ}$ 12.016, of 7 August 2009.

42 Conselho Nacional de Justiça [National Justice Council], Justiça em Números: anoBASE 2013, 39 (2014), available at: http://bit.ly/1OtkVTC. See also ConselHo Nacional de Justiça [National Justice Council], Justiça em Números: Ano-Base 2014 (2015), available at: http://bit.ly/1UDrJju. On excessive judicial review of administrative decisions in Chile, see Supreme Court of Chile [Corte Suprema], Acta 176, Oct. 24, 2014.

43 Laws providing judicial tax enforcement: Art. 653 of the Venezuelan Organic Tax Code [Código Orgánico Tributario da Venezuela] / Decree no 1.434, of 17 November 2014; Brazilian law on tax enforcement [Law on Judicial Collection of Outstanding Tax Claims of the Public Authorities] / Law n ${ }^{\circ}$ 6.830, of 22 September 1980. In contrast, for the admissibility of tax enforcement by the public authorities themselves, see: Articles 98-101 of the Colombian Law of (Judicial and Extrajudicial) Administrative Procedure; 
the necessary prerogatives to conduct independent adjudication and the decisions are made by civil servants with no legal training. As a result, citizens have lost faith in the administrative authorities. This is the reason why the laws of procedure continue assigning to the Judiciary the role of enforcing administrative decisions against individuals. ${ }^{44}$

In fact, judicial enforcement of administrative decisions is dysfunctional. It is a case of role reversal: the administrative authorities cease to exercise their power of "autoexecutoriedade," according to which they should be able to enforce their own decisions without judicial interventions, while the courts enforce administrative decisions instead of protecting the rights and settling the disputes of private claimants.

\section{H. Conventionality Control or ReVIeW of Compliance with InTERnational CONVENTIONS}

According to the case law of the Inter-American Court of Human Rights, all administrative authorities are required to respect the American Convention of Human Rights as interpreted by the Inter-American Court. ${ }^{45}$ That means that whenever the authorities are faced with a national law that is contrary to the American Convention of Human Rights, it should interpret that law in such a way as to comply with that Convention. Nevertheless, if the resulting interpretation tends to interfere with the intended purpose of law then the administrative authority must apply to the Supreme Court for a preliminary opinion on the constitutionality of national laws.

In any case, the system of "conventionality control" is a way of forcing the administrative authorities to respect the supremacy of fundamental rights. To do so, however, the administrative authorities need legal training and prerogatives to act with greater independence vis-à-vis other authorities with contrary political interests.

The doctrine of "conventionality control" favors a harmonious relationship between the Executive and Judiciary powers, which come to act rationally, always searching to protect fundamental rights.

Art. 3 of the Chilean Law of Administrative Procedure; Art. 149 of the General Public Administration Act of Costa Rica; Art. 145 (1) of the Mexican Federal Tax Code [Código Fiscal de la Federación]; Art. 69 (1) of the Tax Code of the Dominican Code [Código Tributário de la República Dominicana] / Law no 11, of 16 May 1992.

44 Marcos de Vasconcellos, Ministros do STJ São Contra Execução Fiscal sem Juiz [Judges of the STJ (Superior Court of Justice) against tax enforcement without a judge], REVISTA Consultor Juríitico (2012).

45 Case of Cabrera García and Montiel Flores v. Mexico, opinion of Eduardo Ferrer MacGregor Poisot, ad hoc Judge Inter-Am.Ct. H.R. (Nov. 26, 2010). Case of Expelled Dominicans and Haitians v. the Dominican Republic, InTER-Aм.Cт. H.R., \ 497 (Aug. 28, 2014) ). See also Eduardo Ferrer Mac-Gregor, The Constitutionalization of International Law in Latin American Conventionality Control: The New Doctrine of the Inter-American Court Of Human Rights, American Society of International LaW-AJil Unbound, 109, 93-99 (2015). 


\section{Model Code of Administrative Procedure in JUdicial and ExtRaJUdicial PROCEEDINGS}

The Ibero-American Institute of Procedural Law's Model Code of Administrative Procedure in Judicial and Administrative Proceedings is not an enforceable law but rather an academic proposal drawn up by legal scholars affiliated with the IberoAmerican Institute that may serve as a model to be followed by Latin American countries of Iberian origin. ${ }^{46}$ The Model Code has incorporated the experiences of certain countries with judicial and extrajudicial proceedings involving administrative law cases. As a result, the Model Code has consolidated such experiences related to basic principles of administrative justice that may be of benefit to other Latin American countries.

The Model Code takes as its premise that administrative authorities lack dispute-resolution proceedings guaranteeing due process and therefore proposes innumerable duties to be imposed on the authorities in dispute-resolution, such as respect for the principles of impartiality, proportionality and legitimate expectations. Consequently, the Code encourages courts to perform close judicial review of both procedural and substantive issues of administrative decisions, including the exercise of their margin of discretion.

I am not aware of any national law in Latin America that has adopted the Model Code or any of its articles. Nevertheless, there is a noticeable trend for case law in Latin American countries to adopt principles similar to those expressed in the Model Code. Here are three examples:

1. Standing to sue is recognized for individuals who claim that their legitimate individual rights or interests have been violated, or are at risk of violation, by a public authority or by an individual holding public office. The legitimacy of class actions has also been recognized for the assertion of diffuse collective interests and to challenge administrative regulations, as well as the possibility, when an administrative decision harms a group of individuals, for any member of injured group or other interested party to sue for compensation for all concerned.

2. Debt enforcement measures are permitted against the administrative authorities, allowing for seizure of public assets that are not allocated to an essential public service. ${ }^{47}$ It is also permitted to impose punitive and coercive fines- that is civil contempt or criminal contempt of court, astreintes -, as well as awards of damages to the individual claimant if the authority delays in complying with a court order.

3. The utilization of suitable means of consensual dispute resolution

46 See Ada Pellegrini Grinover \& Ricardo Perlingeiro et al. Código Modelo de Procesos Administrativos - Judicial y Extrajudicial - para Iberoamérica, Seminário de demandas Repetitivas na Justiça Federal, 29, 107-120 (2014).

47 See art. 170 of the Costa Rican Code of Administrative Justice [Código Procesal Contencioso-Administrativo] / Law no 8.508, of 28 April 2006 . On the subject of public interest (essential service to the community) as grounds for stay of execution of a judgement, see art. 41(a) da Law of Administrative Justice of El Salvador [Ley de la Jurisdicción Contencioso-Administrativa] / Decree n 81, of 14 November 1978. See also art. 110.2 Organic Law of Administrative Justice of Venezuela. 
has been facilitated, subject only to the principle of legality, in order to protect public assets and compliance with the legal system, and to the principle of equality before the law, so that agreements on acts of general scope will have the same effects on every individual in the same situation even if he did not take part in the agreement.

\section{J. Euro-American Model Code of Administrative Justice}

The Euro-American Model Code of Administrative Justice was an initiative of Federal Fluminense University in Rio de Janeiro, in partnership with the University of Speyer, in Germany. ${ }^{48}$ Contributions to the Code were made by legal scholars from the University of Buenos Aires, Universidad Externado da Colombia, the University of São Paulo, the Max Planck Institute of Munich, the University of Erfurt, University of Milan, University of Paris 1 and the University of Jaume 1, in Spain. The Euro-American Model Code was finished in 2010, two years before the Ibero-American Model Code, but it was not published until 2014.

The basic differences between the two model codes are as follows:

1. The Ibero-American Model Code is addressed to Latin American countries, whereas the Euro-American Model Code also includes European countries. Incidentally, the Hungarian Ministry of Justice translated the Euro-American Code into Hungarian and used it in the studies for the reform of Hungarian laws of administrative procedure. ${ }^{49}$

2. The Ibero-American Code includes extrajudicial proceedings, whereas the Euro-American Code is limited to judicial proceedings.

In terms of the contents, there are few differences with respect to administrative adjudication in court. Both model codes adopt the premise that administrative authorities do not perform the function of quasi-judicial adjudication. The procedural principles of both model codes therefore allow for full, close judicial review of administrative decisions.

\footnotetext{
48 See Perlingeiro \& Sommermann, supra note 7.

49 A Közigazgatási Bíráskodás Mintakódexe [Model Code of Administrative JuRISDiction]. KözJogi SzemLe, 3, 65-71 (2015), available at SSRN: https://ssrn.com/ abstract $=2688812$.
} 